\title{
FEATURES OF COMPETITIVENESS ASSESSMENT FOR INSURANCE BUSINESS COMPANIES
}

Competitiveness management issues are acute in any company, in any business and in any industry. Many authors have proposed a large number of not only definitions of competitiveness, but also methods for its calculation. It has been proven that in the case of the insurance business, the concept of "Enterprise competitiveness" should be considered as financial opportunities, which are determined by the specifics of the business, are catalysts of sales, the identification of which will allow the company to pursue a policy of high-quality underwriting. Within the framework of this article, methods for assessing competitiveness and their appropriateness in the insurance business are proposed for use, as well as requirements for assessing the competitiveness of an insurance company are formulated.

Key words: competitiveness, assessment, method, insurance, financial stability, company.

У статті розглянуто тенденції розвитку глобального ринку телекомунікаційних послуг

Problem statement. The issue of assessing competitiveness is acute in any company, in any business, in any industry. If we do not take into account the peculiarities of the activities of enterprises in various industries and their formation of the content of the concept of "enterprise competitiveness", then we can understand "competitiveness" as the company's ability to be more attractive to consumers, partners, suppliers and employees than its competitors. Based on this, the competitiveness of the company is a catalyst for the profit generated at every stage of the enterprise. In accordance with the general conditions, "Enterprise competitiveness" allows you to sell goods in large quantities or at a higher price to the consumer, get more favorable conditions from suppliers, attract more convenient partners on more favorable terms and get the most valuable employees with the least cost and effort.

Each participant in economic activity is in constant competition with direct competitors or substitute products. Unsurprisingly, competition itself has long been studied. There are many methods for assessing the strength and intensity of competition in the market, which are difficult to disagree with. In matters of assessing competitiveness, such specifics are not observed. On the contrary, most valuation methods are either considered theoretical or fit a very narrow segment of the market. There are areas in which such a phenomenon as competitiveness is not considered at all (for example, financial services, in particular insurance). When studying various sources, it was revealed that there are no methods that could be applied in practice to assess the competitiveness of an insurance company.

In this article, it is relevant to study the features of managing the competitiveness of companies in the insurance market, methods for assessing competitiveness and the formation of requirements that must be met by the practical part of assessing the competitiveness of an insurance company.

Analysis of the last days and publications. In modern world literature, the theoretical problems of competition and competitiveness are studied in sufficient detail, but so far the authors have not come to a consensus regarding the definition of competitiveness. The fundamental 
foundations of individual problems of enterprise competitiveness are highlighted in the works of such foreign researchers: J. Lamben, F. Kotler, M. Porter, G. Azov [1], I. Lifits [7], R. Fatkhudinov, etc. Various aspects of ensuring competitiveness objects is the subject of research by such domestic authors as J. Bazilyuk, L. Balabanova [2], A. Voronkova [3], A. Gradov, O. Dragan [4], N. Evtushenko [5], A. Levitskaya [6 ], I. Kirchataya [8], V. Samulyak [9], N. Tarnavskaya [10], A. Tkachenko [11] and a number of other equally eminent scientists.

Regarding with respect to the undoubted achievements of domestic and foreign economic thought, it is worth noting that only certain aspects of the problem of assessing the competitiveness of an enterprise are highlighted in the literature. The issue of the theoretical foundations of managing the competitiveness of insurance companies and the methodological foundations for assessing their competitiveness, taking into account the Ukrainian realities and the specifics of interaction in the market, have not been sufficiently studied. That is why the consideration of theoretical aspects of the characteristics of assessing competitiveness for insurance companies requires further research.

The purpose of the article is to study the features of managing the competitiveness of companies in the insurance market, analyze existing methods for assessing competitiveness, choose the best ones, as well as formulate requirements for assessing the competitiveness of insurance companies.

Presentation of the main material. In modern economic science, it is not customary to distinguish the competitiveness of enterprises in one industry from enterprises in another. It is believed that competitiveness as a phenomenon is the same for manufacturers of fast moving consumer goods, for high-tech production, and for a service provider. However, in practice, this statement loses its meaning. The difference between a company that manufactures computers, for example, and a company in the financial sector is that selling your product to the first organization does not carry any financial risks other than the quality of the products produced. In the worst case, the computer manufacturer will be forced to make warranty repairs or replace the product at its own expense. Transactions in such a business are made in $100 \%$ of customer calls. In this case, the competitiveness of a computer company (like any manufacturer, service company, or retailer) affects the number of customers and is directly proportional to the company's income and profits. [7].

Interesting are the views of scientists who characterize the category of "enterprise competitiveness" as an opportunity to conduct effective economic activity, the result of which is determined by economic indicators. So G. Azov [1] considers the "competitiveness of an enterprise" as the ability to effectively manage its own and borrowed resources in a competitive market. A. Voronkova [3] notes that the competitiveness of an enterprise "is a set of enterprise capabilities (production, innovation, personnel, resource) in various spheres of activity, interacting with each other in a certain way. L. Balabanova [2] reveals the essence of the concept of "enterprise competitiveness" as the level of its competence compared to other competitors in terms of technology, practical skills and professional knowledge of personnel, the level of strategic and current planning, sales policy, management level, communication, the quality of management systems, product manufacturing, and the like. N. Evtushenko [5] proposes to consider the "competitiveness of an enterprise" as a set of capabilities of an enterprise to effectively use its resource potential for the production and sale of competitive products (services) in order to obtain the desired results.

However, the meaningful characteristics of the concept of "enterprise competitiveness" does not take into account the peculiarities of the activities of insurance companies, which are associated with additional financial risks. For an insurance company, every thousand hryvnia received today can result in millions of losses in the short term. In this situation, insurance companies have to choose "their client" from the total volume of consumers who have applied. Often, the success of the business of an insurance company directly depends on the possibility of pursuing a policy of "quality underwriting" - the choice of clients belonging to highly profitable and low-risk segments. 
In this case, the competitiveness of the insurance company is the financial capabilities, which are determined by the specifics of the business, are the catalysts for the volume of sales, the identification of which will allow the company to pursue a policy of high-quality underwriting. The higher the competitiveness, the easier it is for a company to weed out high-risk customers, the more attractive the company becomes for highly profitable customers.

The described features of managing the competitiveness of companies in the insurance market influenced the choice of methods for assessing the competitiveness of these companies and the formation of requirements for the practical application of the competitiveness assessment model.

Let's consider some of the most used methods for assessing the competitiveness of insurance companies, taking into account the meaningful characteristics of the concept of "competitiveness of an insurance company".

Quantitative methods for assessing competitiveness are mainly associated with the calculation of conventional values (points, coefficients) that characterize the level of determining indicators for certain aspects of competitiveness (areas of activity) and their subsequent combination into group and integral indicators. With their help, it is possible to assess the existing capabilities of the company in the competition for strategic areas of management and to approve a balanced management decision. However, some quantitative methods use weights determined by experts, therefore, the technique is not devoid of subjectivity. [6-11].

Qualitative methods for assessing competitiveness (SWOT analysis, method of expert assessments) have a low level of mathematical formalization and are associated with expert assessments. They do not make it possible to use the assessment of the organization's competitiveness in the analysis process, do not differ in scientific rigor, they are characterized by subjectivity and convention. However, qualitative methods are quite flexible, it provides a perspective for assessing real facts, and not abstract numbers if truthful information is applied. [6$11]$.

Matrix methods for assessing competitiveness (McKinsey matrix, BCG matrix, Ansoff matrix, Shell matrix, PIMS matrix), which characterize the market position of the company. The basis of this technique is the consideration of two-dimensional matrices, which are built on the principle of a coordinate system, and the essence of the method involves a marketing assessment of the activities of business entities. These methods are easy to use. The disadvantages of matrix methods are: limitation of the number of characteristics over which the assessment is performed; lack of consideration of the reasons and consideration of an insufficient number of factors; difficulties in assessing the rate of increase in the market and market share of a business entity [6$11]$.

Graphic methods for assessing competitiveness (profile method, competitiveness polygon, radial diagram) are used to construct a competitiveness polygon or radial diagram. the advantages of graphical methods are simplicity and clarity. However, this method does not take into account the different importance of competitiveness factors and does not make it possible to determine the degree of the total criterion of competitiveness, and the use of a large number of characteristics can smooth out its visibility. [6-11].

The considered types of methods for assessing competitiveness show that, depending on the features of systematization, the same method can be included in different groups. For example, the Boston Consulting Group (BCG) matrix is a matrix-based method of reporting results. At the same time, according to the data (variables) of the analysis, it determines the position in the market of the enterprise, and according to the level of decision-making it belongs to the group of strategic methods. Therefore, in practice, the methods are interrelated.

In the process of analyzing the activities of insurance companies, not a single method of assessing competitiveness has been identified that can be used specifically for the insurance business. Moreover, many authors confuse, or even replace the concept of "competitiveness" with the concept of "financial stability" or "solvency", and this is fundamentally wrong. At the same time, it is incorrect to apply any universal assessment methods to insurance companies. Considering 
these features, we offer for insurance companies a comprehensive use of methods for assessing competitiveness, specifically, qualitative methods (SWOT analysis, expert assessment methods), which will characterize the level of management of an insurance company, and methods of financial and economic analysis that will allow to present the level of profitability insurance company.

To improve the quality of research on the activities of insurance companies in the process of determining the level of their competitiveness, we will define the requirements for creating an optimal system for assessing competitiveness:

1. Complexity. Competitiveness has been established - this is a complex phenomenon, which is influenced by almost all factors of the company's activity: market factors (the strength of competition, the availability of substitute goods, the solvency of demand, the level of "insurance education" of the consumer, inflation, etc.), financial factors (own funds (authorized capital) of the company, insurance reserves, reinsurance, portfolio profitability, the presence and size of the branch network, investment activities, tariff policy, etc.), commodity factors (cost, availability of unique products, availability of industry advantages, product significance for the client (level of need), level of service, quality of service), marketing factors (brand (recognition, perception), volume of advertising (media) impact, distribution of sales channels, customer loyalty, etc.).

2. Internal consistency. All factors and parameters of competitiveness should be linked. Changing some parameters should lead to a change in the final result by changing the weight of other parameters. For example: the level of solvency of demand and inflation affect the overall level of competitiveness not directly, but through the weight of the parameter - the cost of the service (product). The education of the population (the ability to accurately determine the quality of insurance services and the level of reliability of the insurer) directly affects the financial group of factors and inversely affects the marketing group.

3. Transparency. Calculations should make it possible to determine the weight of each parameter in the final result, to allow analysis and to determine the weak points of competitiveness in order to strengthen the work of the enterprise in this direction.

4. Possibility of simulating the situation. The competitiveness assessment model should make it possible to predict changes in competitiveness in a changing market situation.

Conclusions. The study analyzed the features of managing the competitiveness of insurance companies. It is proposed to consider the essential characteristics of the concept of "competitiveness of an insurance company" as financial opportunities, which are determined by the specifics of the business, are catalysts of sales, the identification of which will allow the company to pursue a policy of high-quality underwriting.

Taking into account the specifics of the insurance business, the systematization of methods for assessing the competitiveness of an enterprise was carried out. It has been substantiated that all methods for assessing the competitiveness of an enterprise are interrelated and can be used for an integrated approach. It has been established that assessing the competitiveness of insurance companies is a complex multifactorial task, which should be reduced to identifying the most important numerical indicators through the methods of financial and economic analysis of competitiveness, their further assessment in combination with qualitative methods of expert assessments.

The article substantiates the requirements for creating an optimal system for assessing the competitiveness of insurance companies, observing which, it is possible to minimize all the shortcomings of methods for assessing the competitiveness of an enterprise and improve the quality of research on the activities of insurance companies in the process of determining their level of competitiveness in the insurance market.

\section{REFERENCES:}

1. Azoyev G.L., \& Chelenkov A.P. (2006). Konkurentnyye preimushchestva firmy [Competitive advantages of the company]. Moskva. : Novosti. 267. 
2. Balabanova L.V., Kryvenko H.V., \& Balabanova I.V. (2009). Upravlinnya konkurentospromozhnistyu pidpryyemstva [Enterprise Competitiveness Management]. Kyyiv: Vydavnychyy dim «Profesional».

3. Voronkova A.E., Ponomarenko V.P., \& Dibnis H.I. (2000). Pidtrymka konkurentospromozhnoho potentsialu pidpryyemstva [Supporting the competitive potential of the enterprise]. Kyiv: Tekhnika.

4. Drahan, O. I. (2006). Upravlinnia konkurentospromozhnistiu pidpryiemstv: teoretychni aspekty [Enterprise competitiveness management: theoretical aspects]. Kiev : DAKKKiM .

5. Yevtushenko N.O., Drokina N.I., Savenko N.V. (2020) Stratehichne upravlinnya konkurentospromozhnostyu pidpryyemstva: teoretychnyy aspekt [Strategic management of enterprise competitiveness: theoretical aspect ]. Ekonomichnyy prostir - Economic space. Dnipro : PDABA, (156), 129-135.

6. Levytska, A. O. (2013). Metody otsinky konkurentospromozhnosti pidpryiemstva: vitchyzniani ta zakordonni pidkhody do klasyfikatsii. Mekhanizm rehuliuvannia ekonomiky [Methods of assessing the competitiveness of the enterprise: domestic and foreign approaches to classification]. Mekhanizm rehulyuvannya ekonomiky - The mechanism of regulation of the economy, (4), 155-163

7. Lifits I.M. (2004). Formirovaniye i otsenka konkurentosposobnosti tovarov i uslug [Formation and assessment of the competitiveness of goods and services]. Moskva: Yurayt.

8. Kyrchata, I. M. (2007). Otsinka konkurentnoho potentsialu v systemi upravlinnya konkurentospromozhnistyu pidpryyemstva [Assessment of competitive potential in the enterprise competitiveness management system]. Candidate's thesis. Mariupol.

9. Feshchur, R. V., Lebid, T. V. \& Samuliak, V. Yu. (2010). Metody otsiniuvannia konkurentospromozhnosti pidpryiemstv [Methods of assessing the competitiveness of enterprises]. Bulletin of Volyn National University. L.Ukrainka. Economic Sciences Series, (4), 27-32.

10. Tarnavs'ka, N. P. (2008). Upravlinnya konkurentospromozhnistyu pidpryyemstv : teoriya, metodolohiya, praktyka [Management of enterprise competitiveness: theory, methodology, practice]. Ternopil' : Ekonomichna dumka.

11. Tkachenko A. M. \& Kolesnyk É. O. (2019). Metody otsinky konkurentospromozhnosti pidpryyemstva. (Metody otsenki konkurentosposobnosti predpriyatiya). Naukovyy visnyk Poltavs'koho universytetu ekonomiky i torhivli - Nauchnyy vestnik Poltavskogo universiteta ekonomiki i torgovli, (4 (95)), 14-21

\section{Список використаної літератури}

1. Азоев Г.Л., Челенков А.П. Конкурентные преимущества фирмы. Москва: Новости, 2006. $267 \mathrm{c}$.

2. Балабанова Л.В., Кривенко Г.В., Балабанова I.В. Управління конкурентоспроможністю підприємства: Навч. посіб. Київ: Видавничий дім "Професіонал", 2009. $256 \mathrm{c}$.

3. Воронкова А.Е., Пономаренко В.П., Дібніс Г.І. Підтримка конкурентоспроможного потенціалу підприємства. Київ: Техніка, 2000. 152с.

4. Драган О. I. Управління конкурентоспроможністю підприємства: теоретичні аспекти : монографія. Київ: ДАКККіМ, 2006. 155 с.

5. Свтушенко Н.О., Дрокіна Н.І., Савенко Н.В. Стратегічне управління конкурентоспроможностю підприємства: теоретичний аспект. Економічний простір. Дніпро: ПДАБА. 2020. №156. С.129-135

6. Левицька А. О. Методи оцінки конкурентоспроможності підприємства: вітчизняні та закордонні підходи до класифікації. Механізм регулювання економіки. 2013. № 4. С. 155163.

7. Лифиц И.М. Формирование и оценка конкурентоспособности товаров и услуг. Москва: Юрайт, 2004. 224 с. 
8. Кирчата I. М. Оцінка конкурентного потенціалу в системі управління конкурентоспроможністю підприємства : автореф. дис. на здобуття наук. ступеня канд. екон. наук: спец. 08.00.04 «Економіка та управління підприємствами». Маріуполь: ПрДТУ, 2007. $28 \mathrm{c}$.

9. Самуляк В.Ю., Фещур Р.В., Лебідь Т.В. Методи оцінювання конкурентоспроможності підприємств. Вісник Волинського національного університету ім. Л. Українки. Сер. : Економічні науки. 2010. № 4. С. 27-32.

10. Тарнавська Н. П. Управління конкуренто спроможністю підприємств: теорія, методологія, практика: монографія. Тернопіль: Економічна думка, 2008. 570 с.

11. Ткаченко А. М., Колесник Э. О. Методи оцінки конкурентоспроможності підприємства. Науковий вісник Полтавського університету економіки і торгівлі. 2019. № 4 (95), C. 14-21.

ЕВТУШЕНКО НАТАЛЯ ОЛЕКСАНДРІВНА, ХОМИЧ НАТАЛІЯ ОЛЕКСАНДРІВНА. ОСОБЛИВОСТІ ОЦНКИ КОНКУРЕНТОСПРОМОЖНОСТІ ДЛЯ ПІДПРИЕМСТВ СТРАХОВОГО БІЗНЕСУ. Питання управління конкурентоспроможністю стоїть гостро в будь-якій компанії, в будь-якому бізнесі $і$ в будь-якій галузі. Багатьма авторами запропоновано велику кількість не тільки визначень конкурентоспроможності, а й методів $\dddot{\imath}$ розрахунку. Доведено, що в разі страхового бізнесу, поняття «Конкурентоспроможність підприємства» доцільно розглядати як фінансові можливості, які визначені специфікою бізнесу, $\epsilon$ каталізаторами обсягу продажів, виявлення яких дозволить компанії проводити політику якісного андеррайтингу. В рамках иієї статті запропоновані до використання методи оцінки конкурентоспроможності та їх доцільність в страховому бізнесі, а також сформульовані вимоги до оцінки конкурентоспроможності страхової компанії.

Ключові слова: конкурентоспроможність, оцінка, метод, страхування, фінансова стійкість, компанія.

\section{ЕВТУШЕНКО НАТАЛЬЯ АЛЕКСАНДРОВНА, ФОМА НАТАЛЬЯ АЛЕКСАНДРОВНА. ОСОБЕННОСТИ ОЦЕНКИ КОНКУРЕНТОСПОСОБНОСТИ ДЛЯ ПРЕДПРИЯТИЙ СТРАХОВОГО БИЗНЕСА. Вопросы управления} конкурентоспособностью стоит остро в любой компании, в любом бизнесе и в любой отрасли. Многими авторами предложено большое количество не только определений конкурентоспособности, но и методов ее расчета. Доказано, что в случае страхового бизнеса, понятие «Конкурентоспособность предприятия» иелесообразно рассматривать как финансовые возможности, которые определены специификой бизнеса, являются катализаторами объема продаж, выявление которых позволит компании проводить политику качественного андеррайтинга. $B$ рамках этой статье предложень $\kappa$ использованию методы оценки конкурентоспособности и их иелесообразность в страховом бизнесе, а также сформулированы требования к оценке конкурентоспособности страховой компании.

Ключевые слова: конкурентоспособность, оченка, метод, страхование, финансовая устойчивость, компания. 